\title{
Temporal differences across a bio-geographical boundary reveal slow response of sub-littoral benthos to climate change
}

\author{
H. Hinz ${ }^{1,2, *}$, E. Capasso ${ }^{1,2}$, M. Lilley ${ }^{2,3}$, M. Frost ${ }^{2}$, S. R. Jenkins ${ }^{1,2}$ \\ ${ }^{1}$ School of Ocean Sciences, Bangor University, Menai Bridge, Anglesey LL59 5AB, UK \\ ${ }^{2}$ Marine Biological Association of the UK, Citadel Hill, Plymouth PL1 2PB, UK \\ ${ }^{3}$ Department of Biological Sciences, Swansea University, Swansea SA2 8PP, UK
}

\begin{abstract}
The English Channel is located at the biogeographical boundary between the northern Boreal and southern Lusitanian biozones and therefore represents an important area to study the effects of global warming on marine organisms. While the consequences of climatic change in the western English Channel have been relatively well documented for fish, plankton and inter-tidal benthic communities, data highlighting the same effects on the distribution of sub-littoral benthic organisms does, to date, not exist. The present study resurveyed a subset of sites originally surveyed from 1958 to 1959 along the UK coast of the English Channel. The main aims of this resurvey were to describe the present status of benthic communities and to investigate potential temporal changes, in particular distributional changes in western stenothermal 'cold' water and southern Lusitanian 'warm' water species. The increase in water temperature observed since the historic survey was predicted to have caused a contraction in the distribution of cold water species and an extension in the distribution of warm water species. The temporal comparison did not show any clear broad-scale distributional changes in benthic communities consistent with these predictions. Nevertheless, 2 warm water species, the sting winkle Ocenebra erinacea and the introduced American slipper limpet Crepidula fornicata, did show range extensions and increased occurrence, possibly related to climatic warming. Similarly, warm water species previously not recorded by the historic survey were found. The absence of broad-scale temporal differences in sub-tidal communities in response to climatic warming has been reported for other areas and may indicate that these communities respond far more slowly to environmental changes compared to plankton, fish and inter-tidal organisms.
\end{abstract}

KEY WORDS: Climate change · Range-shifts • Benthic macro-fauna • Non-native species English Channel · Long term monitoring

Resale or republication not permitted without written consent of the publisher

\section{INTRODUCTION}

Recognition of increasing anthropogenic pressure on the marine environment, particularly coastal sublittoral habitats, has stimulated wide-ranging research into its impact at an ecosystem level. Experimental studies have been invaluable in furthering our understanding of a variety of anthropogenic drivers and facilitating a move towards a more predictive science. Such work has taken on a variety of forms, from relatively small-scale manipulative studies to larger-scale observational programmes across spatial gradients of perceived impacts (Kaiser et al. 2006, Hinz et al. 2009). However, in attempting to understand how increasing pressure from drivers as wide-ranging as pollution, aggregate extraction, urbanization, demersal fishing, eutrophication and climate change are changing the benthic marine environment, the most direct form of study is examining change through time. In many marine habitats it has been the output of long-term studies which has most vividly demonstrated man's influence in changing marine popu- 
lation and community structures (Myers \& Worm 2003, Hays et al. 2005).

Despite the potential power of long-term studies, a relatively poor understanding of the long-term changes in sub-littoral soft sediments exists compared to other marine habitats. For example, commercial interest has dictated that decadal scale changes in fish populations are relatively well described (Pauly et al. 2001, Myers \& Worm 2003), and recognition of the importance of phytoplankton and zooplankton at the base of the marine food chain has led to numerous long-term studies on these groups (Karl et al. 2001, Beaugrand 2004, Hays et al. 2005). However, documenting long-term change in sub-littoral benthic soft sediments is hampered by the paucity of applicable long-term datasets. Detailed historical surveys of subtidal benthic communities that include quantitative data pre-dating the 1970s are relatively rare. Existing long-term studies are generally limited to European seas, particularly the North Sea and English Channel, and their output has demonstrated the effects of both eutrophication (Kröncke \& Rachor 1992) and demersal fishing impacts (Frid et al. 1999, Rumohr \& Kujawski 2000, Bradshaw et al. 2002, Kaiser \& Spence 2002, Capasso et al. 2010).

There have been few attempts to utilise benthic time series or datasets to assess changes in soft sediment benthic habitats as a consequence of climate change (but see Kröncke et al. 1998, Reiss et al. 2006, Frid et al. 2009, Neumann et al. 2009). However, as early as the 1950s, it was recognised that monitoring this habitat in areas at the boundary of biogeographic provinces could provide indication of a changing climate (Holme 1961). The western English Channel is located at the biogeographic boundary between northern Boreal and southern Lusitanian fauna and has served as an important area for monitoring the effects of global warming on marine organisms (Hawkins et al. 2003). Climatic conditions in the English Channel have changed considerably during the 20th century, with initial warming until the 1950s, a period of cooling after 1962 and significant warming since the 1980s (Luterbacher et al. 2004). While the consequences of climatic change have been relatively well documented for the western English Channel for fish (Southward et al. 1988, Genner et al. 2004, 2010), plankton (Southward 1984, Pitois \& Fox 2006, Gomez \& Souissi 2007, Beaugrand et al. 2009) and inter-tidal benthic communities (Hawkins et al. 2003, 2008, Herbert et al. 2003, 2009, Mieszkowska et al. 2007), no such data exist for sub-tidal benthic organisms. However, the large-scale surveys of Norman Holme (Holme 1961, 1966) do provide a baseline for the distribution of benthic species against which current patterns can be compared. Between 1958 and 1963 Norman Holme conducted 2 large-scale benthic surveys along the length of the English Channel (Holme 1961, 1966). Based on comparisons with the work of Ford (1923) and the general warming trend during this period, he postulated that species that were generally restricted to the western part of the English Channel (western species), with stenothermal life traits (adapted to living at relatively cold stable ocean temperatures), would be negatively affected by any further warming, ultimately leading to a reduction of such species in the English Channel (Holme 1966). He further contemplated that Lusitanian 'warm water species' (Cornubrian and Sarnian species ${ }^{\mathbf{1}}$ ) would extend their distributions in the channel and thrive especially in shallow coastal areas. Warm water species would not only increase their distributional range via migration and larval dispersal from the west (Cornubria or Cornish coast), but also from the Channel Islands (previously 'Sarnia'), arriving mid-channel on the southern coast of England (Holme 1966).

In 2006 we resurveyed parts of Norman Holme's first benthic survey (Holme 1961), covering large extents of the southern coast of England. The main aims of the present resurvey were (1) to describe the current status of benthic communities and (2) to compare our data with the historic survey in order to investigate potential changes in benthic communities. In particular, the paper focuses on the distributional changes of western stenothermal 'cold' water and southern 'warm' water species in relation to climatic changes over the $48 \mathrm{yr}$ period spanning the 2 surveys.

\section{MATERIALS AND METHODS}

Survey area. Between 1958 and 1959 Holme sampled 167 stations along the southern coast of England, extending from Penzance to Folkstone (Holme 1961). Fifty of these sites were revisited in July 2006, across a similar spatial range (Fig. 1).

Sampling procedures adopted in 1958 by Holme. Holme sampled benthic communities along the English Channel using an anchor dredge, a semi-quantitative sampling gear designed to work in coarse sediments (see Holme 1961 for gear design). A single anchor dredge sample was taken at each sampling station. The geographical positioning of each station was obtained via a DECCA navigation system, and readings were converted to latitude and longitude (Holme 1961). Individual dredge samples were treated with considerable variation once onboard. Generally, a sub-sample

\footnotetext{
1Definitions: Cornubrian species are those species Holme typically found on the Cornish coast; Sarnian species are those species Holme typically found off the Channel Islands (previously 'Sarnia')
} 


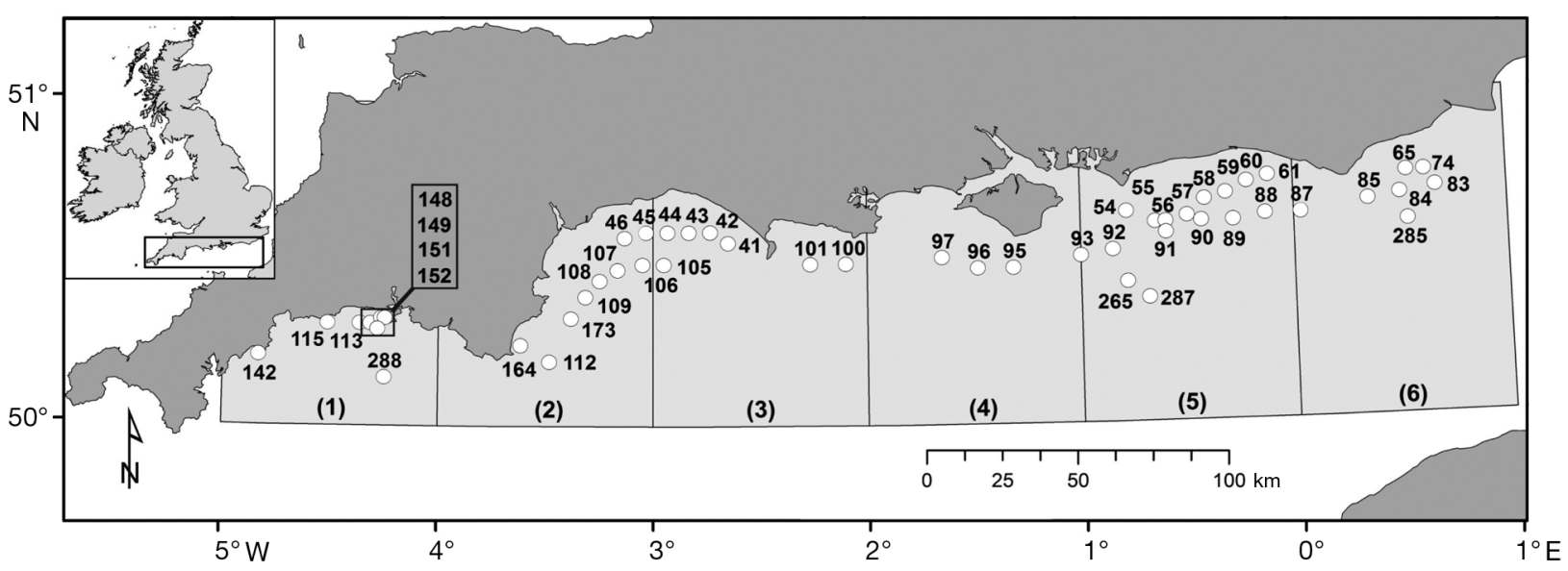

Fig. 1. Map of the 50 stations surveyed by Holme from 1958 to 1959 and resurveyed between July and August 2006. Numbered boxes indicate geographic regions (Regions 1 to 6) for which average sea surface temperatures for the 10 yr period prior to each respective survey were calculated (see Fig. 4)

of the total catch was sieved over $2.2 \mathrm{~mm}$, while the rest of the catch was sorted for conspicuous animals, with respect to their size or abundance, before being hosed down on deck. In addition to or instead of the $2.2 \mathrm{~mm}$ mesh size, coarser sieving (at 5 and $11.5 \mathrm{~mm}$ ) was carried out to process coarser sediment types. The volume of the sieved sub-samples was recorded for some, but not all, stations and expressed as numbers of 'baths' that had a volume of approximately 201 (Holme 1961). Sub-sample sizes varied between 5 and 401 . If and how Holme subsequently standardized subsamples and larger conspicuous fauna sorted from the whole catch is not known. Holme was obviously aware of the inconsistencies in his sampling procedures and the additional bias he therefore introduced to the data, as clearly stated in Holme (1961):

Although there are considerable variations in the samples at each station, due both to the volume of the deposit brought up, and to its subsequent treatment on deck, the numbers of individuals of each species have been noted as a rough guide to their density on the bottom.

Holme identified most species onboard during his research cruises, while preserving species and groups he was unfamiliar with in formalin for later analysis in the laboratory. However, many of these preserved samples were never worked up, and he thus published an incomplete species list, focusing mainly on Mollusca, Echinodermata and conspicuous species of other groups.

Sampling procedures of the resurvey in 2006. In 2006 five anchor dredges were deployed at each station. A single sample was taken at the geographical position given by Holme (1961), and 4 stations were positioned in a circle with a $500 \mathrm{~m}$ radius around this central position. At 12 stations <5 replicates were taken, and stations with $<3$ replicates were excluded from the multivariate analyses (Stns 85, 112, 148, 173), but were considered in the analysis of distribution changes. The anchor dredge used in 2006 had similar dimensions to the one used in 1958 (width $\times$ height $\times$ depth: $62 \times 33 \times 38 \mathrm{~cm}$ ), although the mesh size used $(18 \mathrm{~mm})$ was slightly larger. To protect the inner net from abrasion, a firm outside net with a mesh size of $50 \mathrm{~mm}$ was used. The anchor dredge was deployed each time for approximately $1 \mathrm{~min}$. Each sample was first transferred to a large plastic tub to record the volume (the majority of samples had a volume of over $60 \mathrm{l}$ of sediment) and subsequently emptied on deck. The total catch was first sorted for large conspicuous animals, and then a 201 sub-sample was taken and sieved over 5 and $2 \mathrm{~mm}$. The $5 \mathrm{~mm}$ fraction was sorted onboard, while the $2 \mathrm{~mm}$ fraction was retained and fixed in $4 \%$ buffered formalin solution for later identification in the laboratory. Species abundances in sub-samples were extrapolated using the total volume of catches to estimate abundances. These abundance estimates were combined with the data of the large specimens found in the total catch. The sediment type of the dredge sample was visually assessed and recorded prior to sorting.

Treatment of 1958 and 2006 survey data. To enable comparison with the historical dataset, the 2006 data had to be reduced, as Holme mainly recorded molluscs, echinoderms and a few selected species of other groups. Mollusc and echinoderm species absent in 1958, but recorded in 2006, were included in the analysis if they were conspicuous with respect to size and abundance, following the assumption that these would not have been overlooked by Holmes if present. Other groups, such as polychaetes and crustaceans, were generally excluded, except for the few selected species Holme did record in 1958 (details in Holme 1961). Both 
datasets were updated to the currently accepted species names using the Natural History Museum's (NHM) database to allow direct comparison between surveys.

Limitations of datasets in detecting temporal change. The state of the art in scientific investigations has changed considerably over the course of time (Reise 1982), and this makes an accurate comparison of historic and contemporary datasets difficult. It is therefore essential to understand the limitations of what such comparisons can achieve with respect to detecting temporal change.

In the period from 1958 to 1959 only 1 sample was taken at each station, while 5 replicate samples were collected in 2006. This increased sampling effort per station will have led to a higher probability of catching rare species in 2006. Thus, the detection of a new species at a particular station in 2006 may not reflect a real change, but could merely be an artifact of the higher sampling effort. Nevertheless, some weighted assumptions can be made, which may help to distinguish between this sampling artifact and the true addition of a species to a specific location. If a species did occur in noticeable abundances in most of the replicate samples in 2006, but did not occur between 1958 and 1959 there is a high probability that the observed species represents a true change, as opposed to a sampling artifact. Whilst there are difficulties in detecting the addition of a new species to a specific location because of the higher sampling effort adopted in 2006, the loss of a species can be confidently attributed to a true change. Due to the differences in sampling effort and treatment, results comparing abundance data should be viewed with these limitations in mind.

Status of benthic communities in 2006. The full dataset collected in 2006 (including taxa which were eliminated for the historic comparison) were used to provide a detailed community description for future long-term investigations. Multivariate analysis for these data was performed using PRIMER V.6 (Clark \& Gorley 2006). Abundance data were square root transformed to down-weight the influence of highly abundant species, and a cluster analysis with an integrated SIMPROF-test was performed to identify significant site groupings. The data were then graphically displayed within a multi-dimensional scaling plot. The SIMPER was used to identify characteristic taxa for the clusters highlighted by the SIMPROF-test. To establish which environmental variables best related to the observed community pattern a BIOENV analysis was carried out including depth, sediment type, shea rstress and sea surface temperature (SST; mean annual, mean winter and mean summer temperatures for the period of June 2002 to May 2006). Shear stress data were extracted from a hydrodynamic model of the
English Channel, while mean SSTs were calculated from satellite images (Advanced Very High Resolution Radiometry, AVHRR). Assessed sediment type was converted to a 5 point scale, ranging from soft 1 (mud) to hard 5 (boulders and rocks).

To investigate whether the community pattern found within the full dataset also existed in the reduced dataset of 2006, the RELATE function was run in Primer. This analysis compares 2 ordinations assuming that there is no relationship between them.

SSTs along the English Channel prior to the Holme survey and the resurvey. To examine the differences in water temperatures that organisms were exposed to and which may have influenced distribution patterns prior to the 2 sampling periods modeled average SSTs were compared. Interpolated SST data on a $1^{\circ}$ geographic grid from the HadISST1 model developed at the UK Meteorological Office (Rayner et al. 2003) were used as a proxy for bottom temperatures due to the absence of in situ temperature data for the whole extent of the English Channel. SST models make use of locally available in situ measurements to build temperature time series over larger geographical areas via interpolations. While such model data have their limitations, they often represent the only source of available data (Hughes et al. 2009). Averaged annual as well as average summer and winter SSTs were calculated for the $10 \mathrm{yr}$ periods prior to the sampling events for six $1^{\circ}$ geographic regions (see Fig. 1). The number for and size of each region was determined by the $1^{\circ}$ resolution of HadISST1. The use of SST as a proxy for bottom temperature was justified, as sampling locations were found in relatively shallow waters (average \pm SD depth: $33 \pm 11 \mathrm{~m}$ ) that were tidally mixed throughout the year (Simpson 1998). Only stations in the most western region, Region 1 (Fig. 1), were located in waters that can experience stratification during summer months (Simpson 1998). SSTs for this region are likely to be higher than the actual bottom temperatures. The reader should take note that the data shown here are meant to inform about the relative magnitude of temperature changes between the 2 sampling periods. It is not intended to report on absolute change, and the data limitations should be kept in mind (i.e. model data and use of SST as a surrogate for bottom temperature).

Differences in benthic fauna between historic and contemporary data. Distributions of western stenothermal 'cold' water and Lusitanian 'warm' water species: Holme used the distributions of species he found during his survey of the English Channel to classify species into different biogeographic groups, including 'warm' water species, (described as either Conubrian or Sarnian) and western 'cold' water species, which are generally stenothermal and prefer more stable oceanic 
temperature conditions (Holme 1966). This original classification of species was used, but was updated and modified (if necessary) using distributional information from a large range of sources (Tebble 1976, Graham 1988, Hayward \& Ryland 1999a,b, Southward \& Campbell 2006, Gateway 2009, MarLIN 2009).

The distributional changes of species identified as warm and cold water species were investigated by first dividing the sampling area into the same six $1^{\circ}$ geographic regions, as outlined for the temperature data above (see Fig. 1). The percentage occurrence within each region for both the historic and new data was calculated, and the information was summarized in a table (see Table 4) for visual inspection of any differences between the 2 sampling events.

Species found at stations that were only sampled by the historic survey, but not the resurvey in 2006, were included when establishing range changes. While these stations were not included for the calculation of occurrences of a species, they were considered as a record of presence within the 6 regions.

Community level differences: Multivariate ordinations were used to assess whether community patterns were consistent through time over the whole sampling area. For the reduced 2006 data, the mean of the 5 replicate samples was used for each site. Abundance data of both surveys were square root transformed, and, subsequently, ordinations of both surveys were compared using the RELATE routine.

Benthic community composition at each individual survey site was further examined by investigating the magnitude of temporal change in comparison to present-day spatial variation within each site (reduced 2006 data), a technique previously used in a resurvey of 10 of Holme stations (Kaiser \& Spence 2002) off the coast of France. For each site, a similarity matrix was calculated based on 1 data point for 1958 to 1959 and 5 data points for 2006. This similarity matrix was used to compare the average similarity between the 1950 s sample and the respective 2006 samples (temporal similarity) and the average similarity between 2006 replicate samples (spatial similarity). These values were subsequently compared using 1-way ANOVA.

Sites that indicated a significant temporal change in community structure $(p<0.05)$ were further analyzed using the SIMPER routine to determine which species were responsible for the observed difference. The SIMPER output lists species in the order of their contribution to the observed dissimilarity in percentages. These SIMPER outputs of individual stations that showed significant changes were grouped according to the 2006 identified community clusters. To determine which species contributed most consistently to the temporal dissimilarities within these station groupings the number of times a species occurred in the
SIMPER output (90\% cutoff), the average percentage contribution to the dissimilarities, as well as the average abundances of the species listed for the respective stations were calculated. The species were listed in ranked order; thus, the species with the highest percent occurrence and average contribution to the dissimilarity was the species most important in defining temporal change for a particular station group.

\section{RESULTS}

\section{Status of benthic communities in 2006}

The cluster analysis with the integrated SIMPROF routine of the full 2006 dataset showed the presence of 16 significantly $(\mathrm{p}<0.05)$ distinct clusters (Fig. 2). However, to reduce the complexity of the results and to report on more general community patterns within the English Channel the data were analysed at the lower similarity level of $30 \%$. At this level of similarity, 6 site groupings (A to F) could be identified (Fig. 2), which showed a clear geographical pattern in their spatial distribution (Fig. 3). The characteristic species in each cluster identified by the SIMPER analysis are summarized in Table 1. The overall similarities of clusters, as well as their characteristics with respect to location, average depth and dominant substratum type, are presented in Table 2.

The BIOENV carried out to establish which environmental variable or set of variables best related to the

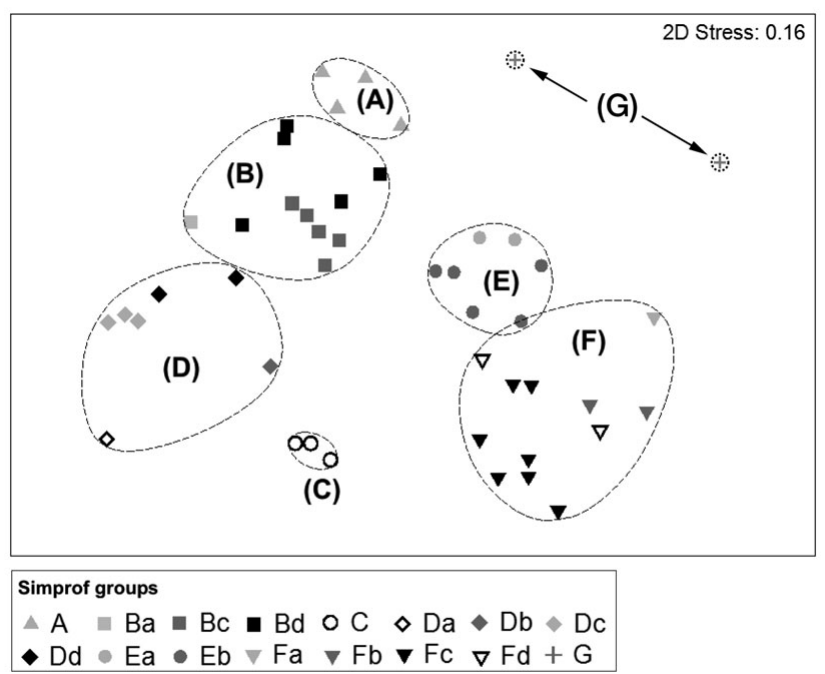

Fig. 2. Significant station groups as identified by the SIMPROF routine using the full abundance data collected in 2006. Groupings A, B, C, D, E, F and G were identified at a $30 \%$ similarity level (dashed ellipses). These groupings were not significant, but were used to make the data more accessible. Group G only consisted of 2 stations and was not considered in further analyses 


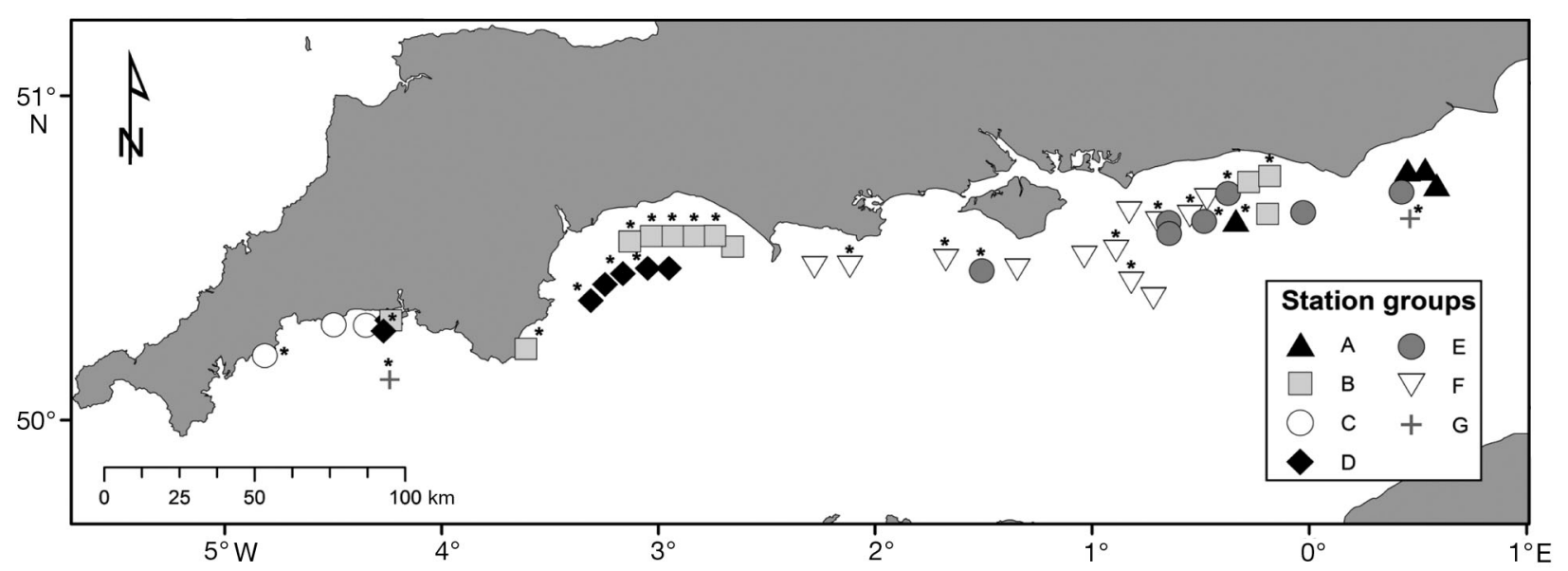

Fig. 3. Distribution of station groups (Groups A, B, C, D, E, F and G) at a $30 \%$ similarity level as identified from the full abundance data collected in 2006. Stations designated with a star indicate stations at which temporal differences in species composition between 1958 to 1959 and 2006 were significantly greater than spatial differences between replicate samples taken at respective sites in 2006

observed community pattern showed that, of the 6 variables used, 4 (shear stress, sediment type, annual mean and annual mean winter SST) showed the best correlation $(\rho=0.569)$. The single environmental variable with the highest correlation coefficient was bottom shear stress $(\rho=0.431)$.

The results of the RELATE analysis, comparing the ordinations of the full dataset of 2006 with those of the reduced dataset, showed they were highly related $(\rho=$ $0.945, \mathrm{p}<0.01$ ), verifying that the community pattern found in the full dataset was preserved in the reduced dataset for 2006. Thus, the decision to base the exploration of temporal changes in local community composition using the reduced dataset on the station groups identified within the 2006 full dataset was justified.

\section{SSTs along the English Channel prior to the Holme survey and the resurvey}

SST data along the English Channel for the $10 \mathrm{yr}$ periods prior to the 2 surveys showed noticeable differences (Fig. 4). Annual average, as well as summer and winter average temperatures, were noticeably higher for the period prior to the 2006 survey within all 6 geographic regions (Fig. 4). Differences were more pronounced for the eastern part of the English Channel (Regions 5 and 6), where temperatures increased in summer by $0.97^{\circ} \mathrm{C}$ and in winter by $0.17^{\circ} \mathrm{C}$ (Fig. 4). The western areas (Regions 1 and 2) experienced far smaller temperature changes, with differences of $0.42^{\circ} \mathrm{C}$ in summer and $0.08^{\circ} \mathrm{C}$ in winter (Fig. 4). These western areas, in particular Region 1, can be stratified during the summer months, with bottom water temperatures generally being colder and more stable than surface temperatures (Simpson 1998).

\section{Differences in benthic fauna comparing historic and contemporary data}

Western stenothermal 'cold' water and Lusitanian 'warm' water species

Lusitanian warm water species showed inconsistent changes in their geographical distribution along the English Channel. Of 8 species, 4 showed an increase in their geographical range, 2 species showed a decrease and 2 exhibited similar distributions compared to 1958-1959 (Table 3). Overall, the occurrence of warm water species at the sites sampled increased throughout the English Channel. This, to some extent, is probably related to the higher sampling effort in 2006 . However, the frequency of occurrence of 3 species, the snapping shrimp Alpheus macrocheles, the sting winkle Ocenebra erinacea and the American slipper limpet Crepidula fornicata showed a noticeable increase, which is likely a reflection of actual change (Table 3). Four warm water species not previously recorded by Holme were found during the 2006 survey (Table 4). In particular, the brittle star Amphiura incana and the burrowing shrimp Athanas nitescens were found within 3 of the 6 geographic regions. All warm water species found by Holme were also recorded in the present study.

Western stenothermal cold water species found within both surveys also showed inconsistent trends (Table 3). While 5 species increased their geographical extent, 3 decreased and a further 7 species were found over the same geographical areas as in 1958 to 1959. Overall, occurrences of cold water species at survey sites were higher in 2006. A prominent increase in occurrence and geographical range was noted for the bivalve Nucula nucleus and for the stalked bar- 
Table 1. Results of the SIMPER analysis using the full abundance data collected during the resurvey in 2006, showing the contribution of species to station groups identified at a similarity level of $30 \%$

\begin{tabular}{|c|c|c|c|c|c|}
\hline Taxon & $\begin{array}{l}\text { Avg. } \\
\text { abun- } \\
\text { dance }\end{array}$ & $\begin{array}{c}\text { Avg. } \\
\text { simi- } \\
\text { larity }(\%)\end{array}$ & $\begin{array}{l}\text { Simi- } \\
\text { larity } \\
\text { (SD) }\end{array}$ & $\begin{array}{c}\text { Contri- } \\
\text { bution } \\
(\%)\end{array}$ & $\begin{array}{c}\text { Cumu- } \\
\text { lative } \\
(\%)\end{array}$ \\
\hline \multicolumn{6}{|l|}{ Group A } \\
\hline Nephtys spp. & 3.31 & 6.21 & 20.29 & 14.25 & 14.25 \\
\hline Ensis sp. & 3.09 & 5.8 & 7.69 & 13.31 & 27.56 \\
\hline Glycera spp. & 2.1 & 3.67 & 2.6 & 8.41 & 35.97 \\
\hline Nemertea & 1.21 & 3.55 & 6.91 & 8.16 & 44.13 \\
\hline Spisula elliptica & 1.18 & 3.55 & 9.74 & 8.15 & 52.28 \\
\hline \multicolumn{6}{|l|}{ Group B } \\
\hline Polinices pulchellus & 4.08 & 3.38 & 2.66 & 8.32 & 8.32 \\
\hline Nephtys spp. & 3.39 & 3.16 & 5.2 & 7.79 & 16.11 \\
\hline Ophiura albida & 6.76 & 3.12 & 0.98 & 7.7 & 23.8 \\
\hline Pagurus bernhardus & 4.28 & 3.07 & 1.28 & 7.57 & 31.38 \\
\hline Hinia spp. & 5.24 & 2.59 & 1.38 & 6.38 & 37.76 \\
\hline Phaxas pellucidus & 1.64 & 1.94 & 4.39 & 4.77 & 42.53 \\
\hline Liocarcinus pusillis & 1.39 & 1.64 & 1.74 & 4.05 & 46.57 \\
\hline Chamelea gallina & 1.93 & 1.34 & 0.9 & 3.3 & 49.87 \\
\hline Ensis sp. & 1.46 & 1.3 & 0.88 & 3.2 & 53.07 \\
\hline \multicolumn{6}{|l|}{ Group C } \\
\hline Notomastus latericeus & 20.79 & 2.27 & 3.36 & 6.02 & 6.02 \\
\hline Tapes rhomboides & 6.25 & 2.18 & 3.71 & 5.79 & 11.81 \\
\hline Hyalinoecia tubicola & 15.21 & 2 & 3.82 & 5.32 & 17.13 \\
\hline Terebellides stroemi & 4.45 & 1.62 & 3.66 & 4.3 & 21.43 \\
\hline Owenia fusiformis & 13.84 & 1.58 & 4.2 & 4.21 & 25.63 \\
\hline Ophiura albida & 4.58 & 1.43 & 3.06 & 3.79 & 29.42 \\
\hline Lumbrineris sp. & 6.3 & 1.37 & 2.25 & 3.64 & 33.06 \\
\hline Glycera spp. & 6.86 & 1.33 & 1.56 & 3.55 & 36.6 \\
\hline Holothurioidea & 6.1 & 1.24 & 1.79 & 3.28 & 39.89 \\
\hline Ebalia spp. & 2.1 & 1.11 & 2.37 & 2.95 & 42.84 \\
\hline Timoclea ovata & 3.53 & 0.93 & 1.59 & 2.48 & 45.32 \\
\hline Nucula nucleus & 2.53 & 0.89 & 4.4 & 2.37 & 47.69 \\
\hline Liocarcinus pusillis & 1.61 & 0.88 & 4.51 & 2.32 & 50.02 \\
\hline \multicolumn{6}{|l|}{ Group D } \\
\hline Nephtys spp. & 17.47 & 6.1 & 4.45 & 14.23 & 14.23 \\
\hline Abra spp. & 23.23 & 3.13 & 1 & 7.3 & 21.53 \\
\hline Amphiura filiformis & 6.45 & 2.8 & 2.26 & 6.54 & 28.07 \\
\hline Chamelea gallina & 4.12 & 2.78 & 2.04 & 6.48 & 34.54 \\
\hline Phaxas pellucidus & 3.64 & 2.57 & 1.97 & 5.99 & 40.54 \\
\hline Nemertea & 2.16 & 2.31 & 3.73 & 5.39 & 45.92 \\
\hline Echinocardium cordatum & 2.75 & 2.03 & 4.68 & 4.75 & 50.67 \\
\hline \multicolumn{6}{|l|}{ Group E } \\
\hline Ophiura albida & 12.18 & 3.15 & 1.41 & 8.09 & 8.09 \\
\hline Pagurus bernhardus & 2.46 & 2.47 & 3.09 & 6.34 & 14.43 \\
\hline Spisula elliptica & 5.11 & 2.05 & 2.26 & 5.26 & 19.69 \\
\hline Timoclea ovata & 2.16 & 1.97 & 2.08 & 5.05 & 24.74 \\
\hline Aequipecten opercularis & 1.69 & 1.95 & 3.54 & 5.01 & 29.75 \\
\hline Pisidia longicornis & 1.32 & 1.78 & 2.27 & 4.55 & 34.3 \\
\hline Psammechinus miliaris & 1.9 & 1.54 & 1.31 & 3.94 & 38.25 \\
\hline Nephtys spp. & 1.19 & 1.5 & 3.55 & 3.83 & 42.08 \\
\hline Ebalia spp. & 1.1 & 1.45 & 1.65 & 3.72 & 45.8 \\
\hline Liocarcinus pusillis & 0.98 & 1.45 & 3.12 & 3.72 & 49.52 \\
\hline Buccinum undatum & 1 & 1.45 & 2.26 & 3.71 & 53.23 \\
\hline \multicolumn{6}{|l|}{ Group F } \\
\hline Pisidia longicornis & 28.2 & 3.38 & 1.89 & 9.22 & 9.22 \\
\hline Crepidula fornicata & 50.84 & 2.29 & 0.76 & 6.23 & 15.45 \\
\hline Pilumnus hirtellus & 12.04 & 2.21 & 2.14 & 6.01 & 21.46 \\
\hline Galathea spp. & 11.49 & 2.2 & 1.95 & 5.99 & 27.46 \\
\hline Ebalia spp. & 5.86 & 1.49 & 2.65 & 4.06 & 31.52 \\
\hline Chlamys varia & 7.9 & 1.39 & 1.49 & 3.8 & 35.32 \\
\hline Psammechinus miliaris & 4.16 & 1.13 & 1.27 & 3.09 & 38.41 \\
\hline Hyas coarctatus & 2.13 & 1.07 & 1.53 & 2.92 & 41.32 \\
\hline Buccinum undatum & 3.06 & 1.06 & 1.31 & 2.88 & 44.2 \\
\hline Pagurus bernhardus & 2.86 & 1 & 1.73 & 2.73 & 46.94 \\
\hline Tapes rhomboides & 6.15 & 0.88 & 1.05 & 2.4 & 49.33 \\
\hline Molgula spp. & 2.5 & 0.85 & 0.93 & 2.32 & 51.66 \\
\hline
\end{tabular}

nacle Scalpellum scalpellum (Table 3). Several western species found by Holme were not recorded during the resurvey (Table 4). However, most of these species were relatively rare and only found at 1 or 2 sites by the historic survey.

\section{Community level differences}

Comparing the community ordinations of the reduced 2006 data with the historical data using the RELATE routine showed that they were significantly correlated ( $\rho=0.397, p<0.01$ ). While this result showed that overall community structure within the English Channel was consistent though time, the relatively low $\rho$-value indicated that there was no precise match.

The multivariate analysis comparing spatial and temporal differences between stations showed that, out of the 44 stations considered for analysis, 22 exhibited significantly ( $p<0.05$ ) greater temporal variability than current spatial variability (Fig. 3, Table 2). The station groups identified in the 2006 data (see Fig. 2) were used to summarize SIMPER outputs of which species were responsible for the observed differences. Station Groups $A$ and $C$ each only contained 1 station and were not presented.

Seven stations in Group B (Figs. 2 \& $3)$, located in the western and eastern parts of the channel, over muddy to gravelly sands, showed significant temporal changes. Contributing to the dissimilarity were the gastropods $\mathrm{Hi}$ nia spp. and Polinices pulchellus, which increased noticeably in abundance (Table 5). At the same time, some species showed a marked decrease in abundance, in particular the sea potato Echinocardium codatum and the small razor clam Phaxas pellucidus (Table 4). At 4 stations, the brittle star Amphiura filfiformis and the burrowing shrimps Callianassa spp. were recorded in relatively high abundances by Holme, but were not recorded by the current resurvey (Table 5). 
Table 2. Summary of station group characteristics. The number of stations within each of the identified station groups, as well as the number of stations that showed significant temporal changes within these groups are shown. Average percentage similarity of the station groups, their location, average depth (m) and dominant substratum types are given

\begin{tabular}{|lcccccc|}
\hline Group & $\begin{array}{c}\text { No. of stations } \\
\text { Total } \\
\text { With signif. } \\
\text { temp. change }\end{array}$ & $\begin{array}{c}\text { Average } \\
\text { similarity } \\
(\%)\end{array}$ & Location & $\begin{array}{c}\text { Mean } \\
\text { depth } \\
(\mathrm{m})\end{array}$ & $\begin{array}{c}\text { Dominant } \\
\text { substratum } \\
\text { types }\end{array}$ \\
\hline A & 4 & 1 & 43.6 & Eastern English Channel only & 34.8 & Gravelly sand \\
B & 11 & 6 & 40.6 & Western and eastern English Channel & 28.6 & Muddy sand to gravelly sand \\
C & 3 & 1 & 37.6 & Western English Channel only & 20.0 & Muddy shelly sand and gravel \\
D & 7 & 3 & 42.8 & Western English Channel & 38.3 & Mud to muddy sand \\
E & 7 & 3 & 39 & Central to eastern English Channel & 33.3 & Sand to gravelly sand \\
F & 12 & 6 & 36.7 & Central English Channel & 35.0 & Gravel with boulders \\
\hline
\end{tabular}
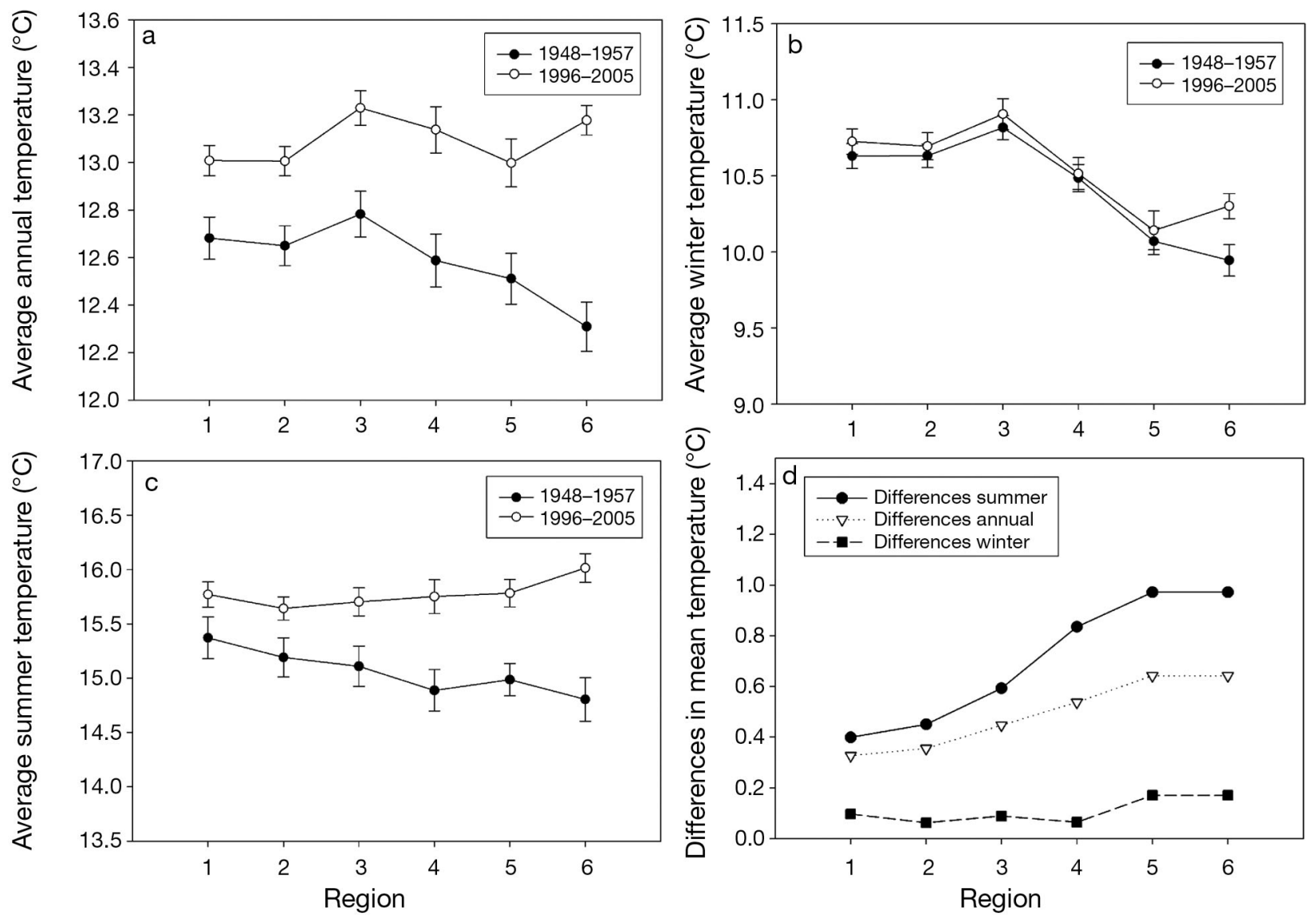

Fig. 4. Changes in sea surface temperature along the English Channel, from $5^{\circ} \mathrm{W}$ to $1^{\circ} \mathrm{E}$ at a latitude of 50 to $51^{\circ} \mathrm{N}$ (Regions 1 to 6, see Fig. 1). Temperatures were calculated for the $10 \mathrm{yr}$ periods prior to the Holme's survey (1948 to 1957) and the resurvey (1996 to 2005) using HadISST1 model outputs (Rayner et al. 2003). (a) Average annual temperatures, (b) average winter temperatures, (c) average summer temperatures, (d) absolute differences in temperatures between the 2 periods

Station Group D (located over mud and fine sand in the western part of the channel) included 4 stations which showed significantly greater temporal differences than current spatial variability. Species contributing most consistently to the dissimilarity were Callianassa spp., Amphiura filiformis and Echinocardium cordatum (Table 5). While Callianassa spp. decreased in abundance, most other species showed an increase. A particularly steep increase was noted for the bivalve Abra spp. and the burrowing anemone Edwardsia spp. (Table 5)

In Group E, located in the central and eastern parts of the channel, only 3 stations showed significant temporal differences in community structure (Fig. 3). The 
Table 3. Presence of southern and western species, expressed as the number of stations where the species was found, in 6 areas from west to east along the English Channel (see Fig. 1 for reference). Present: signifies a species was found by Holme (1958 to 1959) within the region, but the station was not part of the resurvey in 2006 . Arrows indicate an increase $(\uparrow)$, decrease $(\downarrow)$, or no change $(\leftrightarrow)$ in the distributional range of a species along the English Channel. Percentage occurrence is among the 50 stations resurveyed. Bold print: prominent changes in occurrence

\begin{tabular}{|c|c|c|c|c|c|c|c|c|c|}
\hline \multirow{2}{*}{ Species } & \multirow{2}{*}{$\begin{array}{l}\text { Time } \\
\text { period }\end{array}$} & \multirow[b]{2}{*}{$1(8)$} & \multirow{2}{*}{$2(9)$} & \multicolumn{4}{|c|}{ Region (no. of stations) } & \multirow{2}{*}{$\begin{array}{c}\text { Change in } \\
\text { range }\end{array}$} & \multirow{2}{*}{$\begin{array}{c}\text { Occurrence } \\
(\%)\end{array}$} \\
\hline & & & & $3(7)$ & $4(4)$ & $5(15)$ & $6(7)$ & & \\
\hline \multicolumn{10}{|c|}{ Southern 'warm' water species } \\
\hline \multirow[t]{2}{*}{ Alpheus macrocheles } & 1958-1959 & & & 1 & & & & & 2 \\
\hline & 2006 & & & 1 & & 5 & & $\uparrow$ & 12 \\
\hline \multirow[t]{2}{*}{ Crepidula fornicata } & 1958-1959 & & 1 & & 3 & 3 & Present & & 14 \\
\hline & 2006 & & 1 & 6 & 3 & 10 & 2 & $\uparrow$ & 44 \\
\hline \multirow{2}{*}{ Eunicella verrucosa } & 1958-1959 & 1 & & & & & & & 2 \\
\hline & 2006 & 3 & & & & & & $\leftrightarrow$ & 6 \\
\hline \multirow[t]{2}{*}{ Meiosquilla desmaresti } & 1958-1959 & & & Present & Present & 1 & & & 2 \\
\hline & 2006 & & & & 1 & 2 & & $\downarrow$ & 6 \\
\hline \multirow{2}{*}{ Modiolus adriaticus } & 1958-1959 & & & & & 1 & Present & & 2 \\
\hline & 2006 & & & 1 & 1 & 1 & & $\uparrow$ & 6 \\
\hline \multirow{2}{*}{ Ocenebra erinacea } & 1958-1959 & 1 & & & & & 1 & & 4 \\
\hline & 2006 & 1 & & 2 & 3 & 9 & 1 & $\uparrow$ & 32 \\
\hline \multirow{2}{*}{ Pandora inaequivalvis } & 1958-1959 & & & Present & Present & Present & Present & & - \\
\hline & 2006 & & & 2 & & & & $\downarrow$ & 4 \\
\hline \multirow[t]{2}{*}{ Striarca lactea } & 1958-1959 & & 1 & & & & & & 2 \\
\hline & 2006 & & & 2 & & & & $\leftrightarrow$ & 4 \\
\hline \multicolumn{10}{|c|}{ Western stenothermal 'cold' water species } \\
\hline \multirow[t]{2}{*}{ Alpheus glaber } & 1958-1959 & 1 & & Present & & & & & 2 \\
\hline & 2006 & & 1 & 1 & 2 & & & $\uparrow$ & 8 \\
\hline \multirow[t]{2}{*}{ Antalis vulgaris } & $1958-1959$ & & & 1 & & 1 & & & 4 \\
\hline & 2006 & & & 1 & & 1 & 2 & $\uparrow$ & 8 \\
\hline Azorinus chamasolen & 1958-1959 & 1 & 3 & Present & & & & & 8 \\
\hline & 2006 & 3 & 4 & 1 & & & & $\leftrightarrow$ & 16 \\
\hline Chlamys varia & 1958-1959 & & & 2 & 3 & 3 & & & 16 \\
\hline & 2006 & & & 2 & 4 & 7 & & $\leftrightarrow$ & 26 \\
\hline Echinocardium flavescens & 1958-1959 & Present & & & & & & & - \\
\hline & 2006 & 2 & & & & & & $\leftrightarrow$ & 4 \\
\hline Gari tellinella & 1958-1959 & Present & & & & & & & - \\
\hline & 2006 & 3 & & 1 & & & & $\uparrow$ & 8 \\
\hline Labidoplax digitata & 1958-1959 & Present & Present & Present & & & & & - \\
\hline & 2006 & 5 & 6 & 2 & & & & $\leftrightarrow$ & 26 \\
\hline Marthasterias glacialis & 1958-1959 & Present & & & & & & & - \\
\hline & 2006 & 2 & & & & & & $\leftrightarrow$ & 4 \\
\hline Modiolus barbatus & 1958-1959 & & & Present & & & & & - \\
\hline & 2006 & & & 2 & 4 & 4 & & $\uparrow$ & 20 \\
\hline Moerella donacina & 1958-1959 & 1 & 1 & Present & & 2 & 2 & & 12 \\
\hline & 2006 & 4 & & & & 6 & 1 & $\downarrow$ & 22 \\
\hline Nucula nucleus & 1958-1959 & 1 & Present & Present & Present & 1 & Present & & 4 \\
\hline & 2006 & 4 & 4 & 6 & 1 & 10 & 2 & $\leftrightarrow$ & 54 \\
\hline Scalpellum scalpellum & 1958-1959 & 1 & & & & & & & 2 \\
\hline & 2006 & & 1 & 3 & 2 & 3 & 2 & $\uparrow$ & 22 \\
\hline Tapes rhomboides & 1958-1959 & 1 & Present & 2 & 1 & 9 & 3 & & 32 \\
\hline & 2006 & 5 & & 2 & 2 & 9 & 2 & $\downarrow$ & 40 \\
\hline Venus casina & 1958-1959 & & Present & Present & & & & & - \\
\hline & 2006 & & & 1 & & & & $\downarrow$ & 2 \\
\hline Venus verrucosa & 1958-1959 & & & 2 & 1 & 2 & & & 10 \\
\hline & 2006 & & & 2 & 2 & 2 & & $\leftrightarrow$ & 12 \\
\hline
\end{tabular}


Table 4. Southern and western species recorded only by the 1958 to 1959 survey or the resurvey in 2006 . Numbers 1 to 6 correspond to the geographic regions in Fig. 1. Number of stations at which the species was found shown in parentheses

\begin{tabular}{|c|c|c|c|}
\hline Species & $\begin{array}{l}\text { Region } \\
\text { (no. of stations) }\end{array}$ & Species & $\begin{array}{c}\text { Region } \\
\text { (no. of stations) }\end{array}$ \\
\hline \multicolumn{4}{|l|}{ Southern 'warm' water species } \\
\hline & & Amphiura incana & $1(3), 2(1), 5(1)$ \\
\hline & & Athanas nitescens & $1(1), 2(1), 5(1)$ \\
\hline & & Axius stirhynchus & $5(1)$ \\
\hline & & Epitonium clathrus & $2(1), 3(4)$ \\
\hline \multicolumn{4}{|l|}{ Western 'cold' water species } \\
\hline Cochlodesma praetenue & 2(1) & Anseropoda placenta & $1(2)$ \\
\hline Diplodonta rotundata & $1(1), 2(1), 3(1)$ & Boreotrophon truncatus & $4(1)$ \\
\hline Echinocardium pennatifidum & $1(1)$ & Melanella lubrica & $1(1)$ \\
\hline Lyonsia norwegica & $1(1), 5(1)$ & Petricola pholadiformis & $5(1)$ \\
\hline Modiolarca tumida & $3(1), 5(1)$ & Virgularia mirabilis & $1(1)$ \\
\hline Montacuta substriata & $5(1)$ & & \\
\hline Myrtea spinifera & $1(1)$ & & \\
\hline Ophiocomina nigra & $1(5)$ & & \\
\hline Scaphander lignarius & $2(2), 3(1)$ & & \\
\hline
\end{tabular}

species contributing most to temporal dissimilarity, such as the bivalves Spisula elliptica, Timoclea ovata and Aequipecten opercularis, were not recorded by Holme, yet they occurred in moderate abundances in 2006 (Table 5). Similar trends were also observed for the gastropod Buccinum undatum, which was, overall, a rare species in the 1958 to 1959 survey.

Station Group F, located in the central and eastern parts of the channel over hard substrates (gravel with cobblestones and boulders), had 6 stations which showed significant community changes (Fig. 3). Only Buccinum undatum was characteristic of all stations in this group (Table 5). As for the stations in Group E, this species increased in overall abundance with time. In general, most species contributing to temporal dissimilarity increased in abundance. Highly noticeable were increases in the clam Chlamys varia, the slipper limpet Crepidula fornicata and the horse mussel Modiolus barbartus (Table 5).

\section{DISCUSSION}

\section{Temporal distribution changes of benthic species in the English Channel}

In the early 1960s Norman Holme foresaw the changing climatic conditions in the English Channel and postulated that western stenothermal cold water species would be negatively affected by any future warming, ultimately leading to their retreat (Holme 1962). At the same time, he predicted that warming would lead to an increase in southern Lusitanian warm water species within coastal areas. The main route by which warm water species would reach the English coast would be via the Channel Islands and the Cotentin Peninsula; thus, he expected these species to spread from the central channel towards the west and the east (Holme 1966). Despite increases in water temperatures since Holme's survey in the late 1950s, the predicted changes could not clearly be confirmed by the data collected in 2006. Most species which were classified as cold water species showed contemporary occurrences throughout the English Channel similar to those reported by Holme. Few species showed a decrease in their range, although some rarer cold water species were not recorded in 2006, such as the bivalve Diplodonta rotundata, despite the higher sampling effort at that time. Sustained increases in the distributional range of warm water species could not be fully confirmed either. While 4 out of 8 species classified as warm water species showed an increase in their distributional ranges, 2 showed similar ranges to the historic survey and 2 showed a decrease in the extension of their range. The warm water species with the greatest range was the sting winkle Ocenebra erinacea. This species is known to be highly susceptible to cold conditions. The extreme winter of 1962/1963 (Crisp 1964) significantly reduced population levels in the English Channel. The widespread present occurrence of $O$. erinacea demonstrates that this species has recovered, and is now even more common in the English Channel than in the period from 1958 to 1959. This is most possibly related to the milder winter conditions that have persisted over the past decades (Luterbacher et al. 2004). The range extensions of the other 3 warm 
Table 5. Benthic species ranked according to their occurrence in SIMPER tables from analyses of single stations, comparing 1958 to 1959 abundance data and grouped by 2006 station groups. Species average contribution (contr.) to the dissimilarity between years and the average abundance shown in the table relate to the stations that did list respective species in their SIMPER outputs. Arrows indicate an increase $(\uparrow)$ or decrease $(\downarrow)$ in abundance over time

\begin{tabular}{|c|c|c|c|c|c|}
\hline \multirow[t]{2}{*}{ Taxon } & \multirow{2}{*}{$\begin{array}{l}\text { Occur- } \\
\text { rence }\end{array}$} & \multirow{2}{*}{$\begin{array}{c}\text { Avg. } \\
\text { contr. (\%) }\end{array}$} & \multicolumn{2}{|c|}{ Avg. abundance } & \multirow{2}{*}{$\begin{array}{l}\text { Change in } \\
\text { abundance }\end{array}$} \\
\hline & & & $1958-1959$ & 2006 & \\
\hline \multicolumn{6}{|l|}{ Group B } \\
\hline Hinia spp. & 7 & 5.78 & 1.7 & 31.16 & $\uparrow$ \\
\hline Echinocardium cordatum & 7 & 5.64 & 37.68 & 3.01 & $\downarrow$ \\
\hline Polinices pulchellus & 7 & 5 & 0.14 & 30.45 & $\uparrow$ \\
\hline Phaxas pellucidus & 5 & 7.57 & 52.88 & 2.42 & $\downarrow$ \\
\hline Ensis ensis & 5 & 5.58 & 12.77 & 4.2 & $\downarrow$ \\
\hline Chamelea gallina & 5 & 5.23 & 9.47 & 12.93 & $\uparrow$ \\
\hline Nucula nucleus & 5 & 4.26 & 0 & 13.22 & $\uparrow$ \\
\hline Corbula gibba & 5 & 3.8 & 5.47 & 13.61 & $\uparrow$ \\
\hline Ophiura ophiura & 5 & 2.85 & 0 & 7.96 & $\uparrow$ \\
\hline Amphiura filiformis & 4 & 7.79 & 36.12 & 0 & $\downarrow$ \\
\hline Callianassa & 4 & 5.37 & 18.53 & 0 & $\downarrow$ \\
\hline Ophiura albida & 4 & 5.29 & 0.25 & 20.07 & $\uparrow$ \\
\hline Spisula subtruncata & 4 & 5.17 & 43.56 & 10.92 & $\downarrow$ \\
\hline Ensis sp. & 4 & 3.19 & 1 & 5.18 & $\uparrow$ \\
\hline \multicolumn{6}{|l|}{ Group D } \\
\hline Callianassa spp. & 4 & 11.67 & 11.7 & 0.34 & $\downarrow$ \\
\hline Amphiura filiformis & 4 & 4.64 & 1.72 & 6.15 & $\uparrow$ \\
\hline Echinocardium cordatum & 4 & 2.95 & 1.87 & 1.88 & $\uparrow$ \\
\hline Abra spp. & 3 & 22.42 & 0.22 & 67.79 & $\uparrow$ \\
\hline Edwardsia spp. & 3 & 14.43 & 0.22 & 42.99 & $\uparrow$ \\
\hline Phaxas pellucidus & 3 & 6.84 & 0 & 3.75 & $\uparrow$ \\
\hline Chamelea gallina & 3 & 5.91 & 0 & 2.73 & $\uparrow$ \\
\hline Leptosynapta inhaerens & 3 & 3.85 & 1.29 & 0.26 & $\downarrow$ \\
\hline Ophiura ophiura & 2 & 2.34 & 0.25 & 0.37 & $\uparrow$ \\
\hline Azorinus chamasolen & 2 & 2.81 & 0.25 & 0.92 & $\uparrow$ \\
\hline Labidoplax digitata & 2 & 4.51 & 0 & 2.22 & $\uparrow$ \\
\hline Golfingia vulgaris & 2 & 4.86 & 0.5 & 0.27 & $\downarrow$ \\
\hline Leptopentacta elongata & 2 & 4.89 & 1.45 & 4.24 & $\uparrow$ \\
\hline \multicolumn{6}{|l|}{ Group E } \\
\hline Spisula elliptica & 3 & 14.16 & 0 & 26.64 & $\uparrow$ \\
\hline Buccinum undatum & 3 & 4.78 & 0 & 2.78 & $\uparrow$ \\
\hline Timoclea ovata & 3 & 3.69 & 0 & 1.56 & $\uparrow$ \\
\hline Aequipecten opercularis & 3 & 3.09 & 0 & 1.32 & $\uparrow$ \\
\hline Ophiothrix fragilis & 2 & 5.94 & 0 & 2.35 & $\uparrow$ \\
\hline Chlamys varia & 2 & 5.91 & 2 & 0.08 & $\downarrow$ \\
\hline Tapes rhomboides & 2 & 5.41 & 4.5 & 1.84 & $\downarrow$ \\
\hline Laevicardium crassum & 2 & 4.43 & 2.51 & 0.72 & $\downarrow$ \\
\hline Ophiura albida & 2 & 4.14 & 0.5 & 9.37 & $\uparrow$ \\
\hline Echinocyamus pusillus & 2 & 2.88 & 0.5 & 2.62 & $\uparrow$ \\
\hline \multicolumn{6}{|l|}{ Group F } \\
\hline Buccinum undatum & 6 & 4.28 & 0.17 & 21.77 & $\uparrow$ \\
\hline Chlamys varia & 5 & 8.3 & 3.58 & 73.11 & $\uparrow$ \\
\hline Tapes rhomboides & 5 & 7.1 & 21.26 & 29.67 & $\uparrow$ \\
\hline Timoclea ovata & 5 & 5.46 & 1.8 & 24.51 & $\uparrow$ \\
\hline Echinus spp. & 5 & 5.23 & 1.8 & 28.51 & $\uparrow$ \\
\hline Crepidula fornicata & 4 & 20.63 & 1.99 & 181.85 & $\uparrow$ \\
\hline Ocenebra erinacea & 4 & 5.87 & 0 & 27.56 & $\uparrow$ \\
\hline Hinia spp. & 4 & 3.54 & 0.25 & 8.09 & $\uparrow$ \\
\hline Aequipecten opercularis & 4 & 3.52 & 3.72 & 19.67 & $\uparrow$ \\
\hline Fissurellidae & 4 & 2.88 & 0.25 & 6.66 & $\uparrow$ \\
\hline Modiolus barbatus & 3 & 6.17 & 0 & 38.16 & $\uparrow$ \\
\hline Calliostoma zizyphinum & 3 & 4.87 & 0.33 & 20.28 & $\uparrow$ \\
\hline Venus verrucosa & 3 & 4.41 & 16.19 & 12.36 & $\downarrow$ \\
\hline Ostreoida & 3 & 3.66 & 3.88 & 0 & $\downarrow$ \\
\hline Flustra foliacea & 3 & 3.35 & 0.66 & 3 & $\uparrow$ \\
\hline Polinices pulchellus & 3 & 2.16 & 0 & 2.29 & $\uparrow$ \\
\hline Chlamys distorta & 3 & 1.51 & 0 & 1.86 & $\uparrow$ \\
\hline
\end{tabular}

water species were relatively modest. Nevertheless, the American slipper limpet Crepidula fornicata showed considerable increases in occurrence at resurveyed sites. The increases in spatial occurrence of $C$. fornicata demonstrated that this introduced species is now well established. Interestingly, the species was found in subtidal areas down to $\sim 60 \mathrm{~m}$, over rough ground with high current velocities off the Isle of Wight. Previously this species has been reported to occur most often in relatively sheltered shallow bays (Blanchard 1997, Ehrhold et al. 1998, Sauriau et al. 1998). The distribution of $C$. fornicata is thought to be limited by low temperatures (Thieltges et al. 2004); thus, its spread into deeper, generally colder water may be seen as a direct consequence of increased warming. This trend seems to confirm the proposition that climate warming may facilitate the establishment of non-indigenous species (Stachowicz et al. 2002). Four warm water species not recorded by Holme were recorded in 2006. In particular, the brittlestar Amphiura incana and the burrowing shrimp Anthanas nitescens were found at different sites throughout the English Channel.

The absence of any sustained shift in the distribution of cold water species, as predicted by Holme, is unlikely to be an artifact related to the study design or the fundamental differences of the underlying surveys. Due to a higher sampling effort in 2006, the probability of detecting the loss of a species from a particular area was relatively high and any apparent change with respect to the retreat of cold water species should therefore have been detected by this survey. Similarly, the sampling regime would have been very sensitive towards detecting range extensions and occurrences of warm water species, with the tendency towards overestimating these; thus, the findings of the present study with respect to the absence of any broadscale changes are supported. Overestimations of range extensions and occurrences may be particularly relevant for 
rare species for which only relatively modest changes were reported. However, the stark distributional changes reported for Ocenebra erinacea and Crepidula fornicata are unlikely to represent sampling bias.

A similar absence of sustained changes in the temporal distributions of sub-tidal benthic species, despite climatic warming, has been described for other temperate areas (Neumann et al. 2009, Stuart-Smith et al. 2010). In contrast to plankton (Beaugrand et al. 2009) and fish (Genner et al. 2004, Hiddink et al. 2008), which have been shown to rapidly respond to changes in climatic conditions due to their fast life cycle and mobility, respectively, sub-tidal benthic organisms seem to show slower responses. Changes in the distributions of benthic organisms are, in general, dependent on factors that are also important in terrestrial systems, such as dispersal rates and habitat availability (Honnay et al. 2002, Iverson et al. 2004). Lack of habitat within dispersal distance may be linked to the absence of sustained increases in southern species in the English Channel, but it fails to explain the persistence of cold water species in a warming environment. Hawkins et al. (2009) suggest that the lack of retreat by cold water species (e.g. Mieszkowska et al. 2006, Lima et al. 2007) may be a consequence of competitive superiority over warm water counterparts, while Lima et al. (2007) speculated that cold water species may be able to maintain their distribution if warming temperatures only have sublethal effects on the organism, e.g. reducing reproductive output. Under such as scenario the occurrence of occasional cold pulses may be sufficient to allow the successful reproduction needed to maintain local populations.

\section{Temporal changes in local community composition}

In the present study we also explored more localized differences in benthic communities between the 2 sampling periods. In the western part of the English Channel, in the area of Lyme Bay where trawling intensities are high (Witt \& Godley 2007), there were clear changes in species composition between the 2 surveys. Abundances of Echinocardium cordatum (irregular urchin), Amphiura filiformis (brittle star) and Calianassa spp. (burrowing shrimp) decreased, while gastropods such as Hinia spp. and Polinices polianus increased. E. cordatum and A. filiformis are known to be vulnerable to trawling activities (Hinz et al. 2009), whilst the gastropods Hinia spp. and $P$. polianus are both scavengers that may profit in areas of fishing disturbance (Jennings \& Kaiser 1998).

Community composition in the central parts of the English Channel, a region of strong tidal currents and hard substrates, also showed noticeable changes. Spe- cies such as the common whelk Buccinum undatum, the bivalves Clamys varia and Timoclea ovata, and the non-native American slipper limpet Crepidula fornicata all increased in their occurrence and in abundance. While some of these increases may be related to the higher sampling effort adopted in 2006, the magnitude of the changes described seems unlikely to be related to sampling bias alone. The whelk $B$. undatum is, again, a scavenging species which may benefit from fishing activities (see above). Increases in the 2 bivalve species $C$. varia and $T$. ovata may be related to climatic changes. Higher abundances of bivalves, in particular, have been noted for other areas of the United Kingdom. For example, despite relatively high levels of exploitation, stock densities of great scallops Pecten maximus and queen scallops Aequipecten opercularis have increased over the past $20 \mathrm{yr}$ at the Isle of Man (Beukers-Stewart et al. 2003, Shephard et al. 2010); this increase has been linked to rises in water temperature (Shephard et al. 2010). Whether the observed increases in other bivalve species in this area are linked to the warming trend is unclear.

\section{CONCLUSIONS}

In summary, this resurvey of historical sampling sites showed limited changes in the distribution patterns of individual species that could, potentially, be linked to climatic changes; however, it did not reveal broadscale, sustained changes in the distributions of subtidal benthic communities. While the limitations of the study have been extensively discussed, we confidently conclude that the level of community change revealed in other offshore taxa, such as plankton and fish, has, for the most part, not occurred in the sub-tidal, softsediment benthos. This is not to say that small-scale or subtle changes have not occurred. In order to detect such change more accurately in the future, benthic monitoring programs, along with an increased understanding of the temperature effects on benthic species, are required. For example, the current temperature tolerances of benthic organisms and, thus, their classifications into different geographical regions (e.g. Lusitanian, Boreal) are still being inferred from distribution patterns based on past surveys. Future studies on climate change should probably concentrate on the temperature tolerances of a few selected species serving as indicator species. Ideally these would then be routinely sampled, allowing the overall sampling effort to be expended in a more focused manner. Within coastal areas, such as the English Channel, monitoring subtidal benthic species with respect to climate change may be more cost effective (and allow more subtle effects to be detected) if done in transects from shallow 
water into deeper water rather than monitoring distribution changes along the coast as is done for inter-tidal organisms (Mieszkowska et al. 2006, Hawkins et al. 2008). Shallow coastal areas may experience greater temperature changes, which may lead to shifts in the distribution of species along a depth gradient. Such an approach would also determine potential changes due to the predicted increase in the frequency and intensity of storms, with species that are intolerant to disturbances moving offshore (Harley et al. 2006).

Acknowledgements. We thank the Aggregate Levy Sustainability Fund and Natural England for funding this work. Furthermore, we are grateful to the School of Ocean Sciences for making their research vessel the 'Prince Madog' available for the survey in 2006. Thanks also to Peter Rendle, Marika Galananidi, Helen Bloomfield and Georgina Budd for their help in organizing and conducting the research cruise. The authors thank the NERC Earth Observation Data Acquisition and Analysis Service (NEODAAS), as well as the Centre for Environment, Fisheries \& Aquaculture Science (CEFAS, Lowestoft) for supplying data for this study. Thanks also to the anonymous reviewers who helped to improve this manuscript.

\section{LITERATURE CITED}

Beaugrand G (2004) The North Sea regime shift: evidence, causes, mechanisms and consequences. Prog Oceanogr 60:245-262

Beaugrand G, Luczak C, Edwards M (2009) Rapid biogeographical plankton shifts in the North Atlantic Ocean. Glob Change Biol 15:1790-1803

Beukers-Stewart BD, Mosley MWJ, Brand AR (2003) Population dynamics and predictions in the Isle of Man fishery for the great scallop (Pecten maximus L.). ICES J Mar Sci 60:224-242

Blanchard M (1997) Spread of slipper limpit Crepidula fornicata (L., 1758) in Europe. Current state and consequences. Sci Mar 61:109-118

Bradshaw C, Veale LO, Brand AR (2002) The role of scallopdredge disturbance in long-term changes in Irish Sea benthic communities: a re-analysis of an historical dataset. J Sea Res 47:161-184

Capasso E, Jenkins SR, Frost M, Hinz H (2010) Investigation of benthic community change over a century-wide scale in the western English Channel. J Mar Biol Assoc UK 90(6): $1161-1172$

Clark KR, Gorley RN (2006) Primer V6: user manual. Plymouth Marine Laboratory, Plymouth

Crisp DJ (1964) The effects of the severe winter of 1962-63 on marine life in Britain. J Anim Ecol 33:165-210

Ehrhold A, Blanchard M, Auffret JP, Garlan T (1998) The role of Crepidula proliferation in the modification of the sedimentary tidal environment in Mont-Saint-Michel Bay (The Channel, France). CR Acad Sci Ser II A 327:583-588

Ford E (1923) Animal communities of the level sea-bottom in the waters adjacent Plymouth. J Mar Biol Assoc UK 13:165-224

Frid C, Clark R, Hall J (1999) Long-term changes in the benthos on a heavily fished ground of the NE coast of England. Mar Ecol Prog Ser 188:13-20
Frid CLJ, Garwood PR, Robinson LA (2009) Observing change in a North Sea benthic system: a 33 year time series. J Mar Syst 77:227-236

Gateway N (2009) The national biodiversity network. National Biodiversity Network Trust, Nottingham

- Genner MJ, Sims DW, Wearmouth VJ, Southall EJ, Southward AJ, Henderson PA, Hawkins SJ (2004) Regional climatic warming drives long-term community changes of British marine fish. Proc R Soc Lond B Biol Sci 271: $655-661$

> Genner MJ, Sims DW, Southward AJ, Budd GC and others (2010) Body-size dependent responses of a marine fish assemblage to climate change and fishing over a centurylong scale. Glob Change Biol 16:517-527

> Gomez F, Souissi S (2007) Unusual diatoms linked to climatic events in the northeastern English Channel. J Sea Res 58: 283-290

Graham A (1988) Molluscs: prosobranch and pyramidellid gastropods, Vol 2. The Linnean Society of London and The Estuarine and Brackish-Water Science Association, London

Harley CDG, Hughes AR, Hultgren KM, Miner BG and others (2006) The impacts of climate change in coastal marine systems. Ecol Lett 9:228-241

> Hawkins SJ, Southward AJ, Genner MJ (2003) Detection of environmental change - evidence from the western English Channel. Sci Total Environ 310:245-256

> Hawkins SJ, Moore PJ, Burrows MT, Poloczanska E and others (2008) Complex interactions in a rapidly changing world: responses of rocky shore communities to recent climate change. Clim Res 37:123-133

> Hawkins SJ, Sugden HE, Mieszkowska N, Moore PJ and others (2009) Consequences of climate-driven biodiversity changes for ecosystem functioning of North European rocky shores. Mar Ecol Prog Ser 396:245-259

> Hays GC, Richardson AJ, Robinson C (2005) Climate change and marine plankton. Trends Ecol Evol 20:337-344

Hayward PJ, Ryland JS (1999a) The marine fauna of the British Isles and north-west Europe, Vol 2. Oxford University Press, Oxford

Hayward PJ, Ryland JS (1999b) The marine fauna of the British Isles and north-west Europe, Vol 1. Oxford University Press, Oxford

Herbert RJH, Hawkins SJ, Sheader M, Southward AJ (2003) Range extension and reproduction of the barnacle Balanus perforatus in the eastern English Channel. J Mar Biol Assoc UK 83:73-82

> Herbert RJH, Southward AJ, Clarke RT, Sheader M, Hawkins SJ (2009) Persistent border: an analysis of the geographic boundary of an intertidal species. Mar Ecol Prog Ser 379: $135-150$

Hiddink JG, ter Hofstede R (2008) Climate-induced increases in species richness of marine fishes. Global Change Biol 14:453-460

> Hinz H, Prieto V, Kaiser MJ (2009) Trawl disturbance on benthic communities: chronic effects and experimental predictions. Ecol Appl 19:761-773

Holme NA (1961) The bottom fauna of the English Channel. J Mar Biol Assoc UK 41:397-461

Holme NA (1966) The bottom fauna of the English Channel. Part II. J Mar Biol Assoc UK 46:401-493

- Honnay O, Verheyen K, Butaye J, Jacquemyn H, Bossuyt B, Hermy M (2002) Possible effects of habitat fragmentation and climate change on the range of forest plant species. Ecol Lett 5:525-530

> Hughes SL, Holliday NP, Colbourne E, Ozhigin V, Valdimarsson H, Osterhus S, Wiltshire K (2009) Comparison of in situ 
time-series of temperature with gridded sea surface temperature datasets in the North Atlantic. ICES J Mar Sci 66: 1467-1479

Iverson LR, Schwartz MW, Prasad AM (2004) How fast and far might tree species migrate in the eastern United States due to climate change? Glob Ecol Biogeogr 13:209-219

Jennings S, Kaiser MJ (1998) The effects of fishing on marine ecosystems. In: Advances in marine biology, Vol 34. Academic Press, London, p 201-352

Kaiser MJ, Spence FE (2002) Inconsistent temporal changes in the megabenthos of the English Channel. Mar Biol 141: 321-331

Kaiser MJ, Clarke KR, Hinz H, Austen MCV, Somerfield PJ, Karakassis I (2006) Global analysis of response and recovery of benthic biota to fishing. Mar Ecol Prog Ser 311:1-14

Karl DM, Bidigare RR, Letelier RM (2001) Long-term changes in plankton community structure and productivity in the North Pacific Subtropical Gyre: the domain shift hypothesis. Deep-Sea Res II 48:1449-1470

Kröncke I, Rachor E (1992) Macrofauna investigations along a transect from the inner German Bight towards the Dogger Bank. Mar Ecol Prog Ser 91:269-276

Kröncke I, Dippner JW, Heyen H, Zeiss B (1998) Long-term changes in macrofaunal communities off Norderney (East Frisia, Germany) in relation to climate variability. Mar Ecol Prog Ser 167:25-36

Lima FP, Ribeiro PA, Queiroz N, Hawkins SJ, Santos AM (2007) Do distributional shifts of northern and southern species of algae match the warming pattern? Glob Change Biol 13:2592-2604

Luterbacher J, Dietrich D, Xoplaki E, Grosjean M, Wanner H (2004) European seasonal and annual temperature variability, trends, and extremes since 1500. Science 303: 1499-1503

MarLIN (Marine Life Information Network) (2009) Education and outreach. Marine Biological Association of the United Kingdom, Plymouth

Mieszkowska N, Kendall MA, Hawkins SJ, Leaper R, Williamson P, Hardman-Mountford NJ, Southward AJ (2006) Changes in the range of some common rocky shore species in Britain - a response to climate change? Hydrobiologia 555:241-251

Mieszkowska N, Hawkins SJ, Burrows MT, Kendall MA (2007) Long-term changes in the geographic distribution and population structures of Osilinus lineatus (Gastropoda: Trochidae) in Britain and Ireland. J Mar Biol Assoc UK 87:537-545

- Myers RA, Worm B (2003) Rapid worldwide depletion of predatory fish communities. Nature 423:280-283

> Neumann H, Ehrich S, Kröncke I (2009) Variability of epifauna and temperature in the northern North Sea. Mar Biol 156:1817-1826

Pauly D, Palomares ML, Froese R, Sa-a P, Vakily M, Preikshot D, Wallace S (2001) Fishing down Canadian aquatic food webs. Can J Fish Aquat Sci 58:51-62

Pitois SG, Fox CJ (2006) Long-term changes in zooplankton

Editorial responsibility: Paul Snelgrove,

St. John's, Newfoundland, Canada biomass concentration and mean size over the Northwest European shelf inferred from continuous plankton recorder data. ICES J Mar Sci 63:785-798

Rayner NA, Parker DE, Horton EB, Folland CK and others (2003) Global analyses of sea surface temperature, sea ice, and night marine air temperature since the late nineteenth century. J Geophys Res 108:4407-4437

Reise K (1982) Long-term changes in the macrobenthic invertebrate fauna of the Wadden Sea: Are polychaetes about to take over? Neth J Sea Res 16:29-36

Reiss H, Meybohm K, Kröncke I (2006) Cold winter effects on benthic macrofauna communities in near- and offshore regions of the North Sea. Helgol Mar Res 60:224-238

> Rumohr H, Kujawski T (2000) The impact of trawl fishery on the epifauna of the southern North Sea. ICES J Mar Sci 57:1389-1394

Sauriau PG, Pichocki-Seyfried C, Walker P, De Montaudouin X, Palud C, Heral M (1998) Crepidula fornicata L. (Mollusca, Gastropoda) in the Marennes-Oleron Bay: side-scan sonar mapping of sub-tidal beds and stock assessment. Oceanol Acta 21:353-362

> Shephard S, Beukers-Stewart B, Hiddink JG, Brand AR, Kaiser MJ (2010) Strengthening recruitment of exploited scallops Pecten maximus with ocean warming. Mar Biol 157:91-97

Simpson JH (1998) The Celtic Seas, coastal segment (19, E). In: The sea, Vol 11. John Wiley \& Sons, New York, NY, p 659

Southward AJ (1984) Fluctuations in the 'indicator' chaetognaths Sagitta elegans and Sagitta setosa in the western Channel. Oceanol Acta 7:229-239

Southward EC, Campbell AC (2006) Echinoderms, Vol 56. Field Studies Council, Linnean Society of London, Shrewsbury

Southward AJ, Boalch GT, Maddock L (1988) Fluctuations in the herring and pilchard fisheries of Devon and Cornwall linked to change in climate since the 16th century. J Mar Biol Assoc UK 68:423-445

Stachowicz JJ, Terwin JR, Whitlatch RB, Osman RW (2002) Linking climate change and biological invasions: ocean warming facilitates nonindigenous species invasions. Proc Natl Acad Sci USA 99:15497-15500

Stuart-Smith RD, Barrett NS, Stevenson DG, Graham JD (2010) Stability in temperate reef communities over a decadal time scale despite concurrent ocean warming. Glob Change Biol 16:122-134

Tebble N (1976) British bivalve seashells. A handbook for identification. Her Majesty's Stationary Office, London

Thieltges DW, Strasser M, van Beusekom JEE, Reise K (2004) Too cold to prosper-winter mortality prevents population increase of the introduced American slipper limpet Crepidula fornicata in northern Europe. J Exp Mar Biol Ecol 311:375-391

Witt MJ, Godley BJ (2007) A step towards seascape scale conservation: using vessel monitoring systems (VMS) to map fishing activity. PLoS ONE 2:e1111

Submitted: March 3, 2010; Accepted: November 29, 2010 Proofs received from author(s): February 3, 2011 